\title{
Synergistic chiral iminium and palladium catalysis: Highly regio- and enantioselective [3 + 2] annulation reaction of 2-vinylcyclopropanes with enals
}

\author{
Haipan Zhu ${ }^{1,2}$, Peile $\mathrm{Du}^{2}$, Jianjun Li ${ }^{1}$, Ziyang Liao ${ }^{1}$, Guohua Liu ${ }^{2}$, Hao Li ${ }^{* 1}$ \\ and Wei Wang ${ }^{* 1,3}$
}

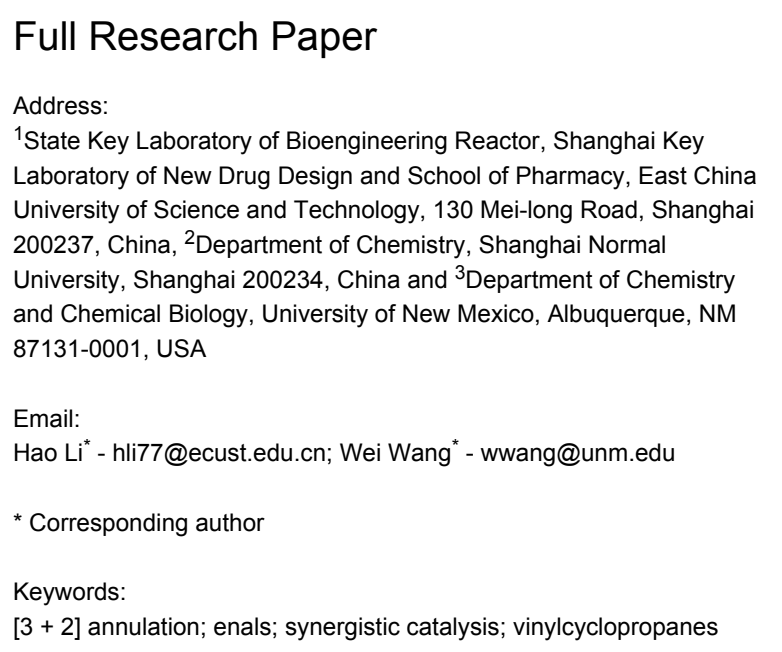

[3 + 2] annulation; enals; synergistic catalysis; vinylcyclopropanes

Beilstein J. Org. Chem. 2016, 12, 1340-1347. doi:10.3762/bjoc. 12.127

Received: 29 March 2016

Accepted: 02 June 2016

Published: 29 June 2016

This article is part of the Thematic Series "Strategies in asymmetric catalysis".

Guest Editor: T. P. Yoon

(C) 2016 Zhu et al.; licensee Beilstein-Institut. License and terms: see end of document.

\begin{abstract}
A cooperative catalytic strategy of chiral iminium catalysis by regioselective activation of the $\mathrm{C}=\mathrm{C}$ bond in enals and a transition metal promoting to open the 2-vinylcyclopropanes for highly regio- and enantioselective [3+2] cycloaddition reaction of 2-vinylcyclopropanes with $\alpha, \beta$-unsaturated aldehydes has been developed.
\end{abstract}

\section{Introduction}

The power of "donor-acceptor" (D-A) cyclopropanes as versatile 1,3-dipolar components is fuelled by its capacity of serving a complementary approach to a wide array of 5-membered ring structures, which are difficult or impossible to access by classic $[3+2]$ cycloaddition reactions [1-34]. In recent years, significant efforts have been devoted to developing a catalytic enantioselective version of the processes. In this context, the D-A cyclopropanes have been applied for the reaction with highly active dipolarophiles, such as electrophilic $\mathrm{C}=\mathrm{O}$ [35], e.g., alde- hydes [36-38], ketones [38,39], and imines [40], and nucleophilic enol ethers [38,41], enamides [42], and indoles [43]. Nonetheless, the reactions with the $\alpha, \beta$-unsaturated aldehydes and ketones face important challenges. To the best of our knowledge, so far merely two catalyst manifolds have been realized to effect the transformations with $\mathrm{C}=\mathrm{C}$ double bonds instead of $\mathrm{C}=\mathrm{O}$ in the $\alpha, \beta$-unsaturated systems. Tsuji described the first organometallic promoted non-asymmetric reaction between D-A cyclopropanes and methyl vinyl ketone and $\alpha, \beta$-unsatu- 
rated esters [44]. Trost and co-workers orchestrated the only example of the enantioselective reaction of $\mathrm{D}-\mathrm{A}$ cyclopropanes with $\mathrm{C}=\mathrm{C}$ double bonds with Meldrum's acid and alkylidenes or azlactone alkylidenes, catalyzed by the chiral Trost $\mathrm{Pd}(0)$-complexes [45]. However, it is difficult to apply the catalytic system for the regio-controlled reaction with $\mathrm{C}=\mathrm{C}$ bonds in $\alpha, \beta$-unsaturated carbonyl compounds, particularly enals. The highly active aldehyde functionality reacts more favorably with the D-A cyclopropane resulting 1,3-dipoles, as elegantly demonstrated by Johnson and Waser for the formation of chiral tetrahydrofurans (Scheme 1, reaction 1) [36,38]. Achieving a regioselective control at the $\mathrm{C}=\mathrm{C}$ bond rather than at $\mathrm{C}=\mathrm{O}$ in enals represents a challenge and has not been reported.

Synergistic catalysis is a very important and useful strategy in organic synthesis by offering power for improving reaction efficiency and/or realizing impossible processes [46-55]. Recently, we developed an enantioselective addition of aldehydes to vinylpyridines and vinylarenes catalyzed by synergistic catalysis of iminium catalyst and Brønsted acid [56]. Herein we wish to disclose the first synergistic catalytic enantioselective $[3+2]$ annulation reaction between 2-vinylcyclopropanes and enals via 1,4-addition (Scheme 1, reaction 2). The process proceeds highly regio- and enantioselectively with $\mathrm{C}=\mathrm{C}$ bonds in enals. Notably, a synergistic catalytic system is implemented and makes this previously inaccessible [3+2] annulation transformation possible.

\section{Results and Discussion}

To render the $[3+2]$ annulation reaction to selectively act on the $\mathrm{C}=\mathrm{C}$ double bond rather than on the aldehyde in enals $\mathbf{1}$, we proposed a new cooperative iminium and Lewis acid (LA) catalysis strategy (Scheme 1, reaction 2) [49,50,57-76]. The iminium catalysis plays an important dual role in the process. The formed iminium ion $\mathbf{4}$ derived from aldehyde $\mathbf{1}$ and an amine catalyst activates the $\mathrm{C}=\mathrm{C}$ bond and sterically blocks the attack of the $\mathrm{C}=\mathrm{N}$ iminium ion functionality posed by the bulky amine catalyst. In parallel, a LA promotes to open the D-A cyclopropanes 2 . The cooperative activation of two independent substrates by respective iminium and Lewis acid catalysis may enable an unprecedented catalytic regio- and enantioselective $[3+2]$ annulation process, which offers a new approach to synthetically important heavily functionalized chiral cyclopentane structures $\mathbf{3}$, bearing at least 3 stereogenic centers in this one-pot operation $[77,78]$.

To test the feasibility of the designed [3+2] annulation process [79-94], we started our investigation by carrying out the reaction between the commonly used D-A system dimethyl 2-vinylcyclopropane-1,1-dicarboxylate (1a) and trans-cinnamaldehyde (2a) catalyzed in the presence of a LA and chiral amine I in $\mathrm{CH}_{2} \mathrm{Cl}_{2}$ at $\mathrm{rt}$ for $48 \mathrm{~h}$ (Table 1). A series of Lewis acids were initially screened. $\mathrm{FeCl}_{3}$ and $\mathrm{Cu}(\mathrm{OTf})_{2}$ gave the 1,2-cycloaddition product tetrahydrofuran $4 \mathbf{a}$ (Table 1 , entries 1 and 2). It is also disappointing that others Lewis acids, such as $\mathrm{CuCl}_{2}$,

a) Established studies: $\mathrm{C}=\mathrm{O}$ in enals engaged in [3+2] annulation:

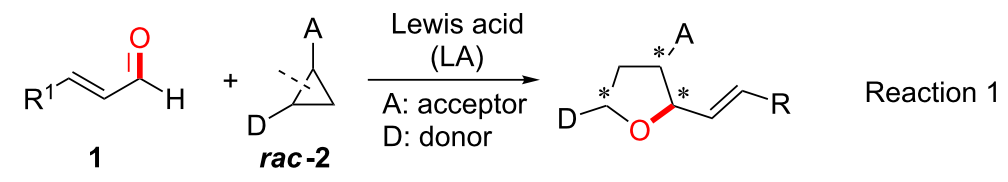

b) This study: $\mathrm{C}=\mathrm{C}$ in enals engaged in $[3+2]$ annulation:
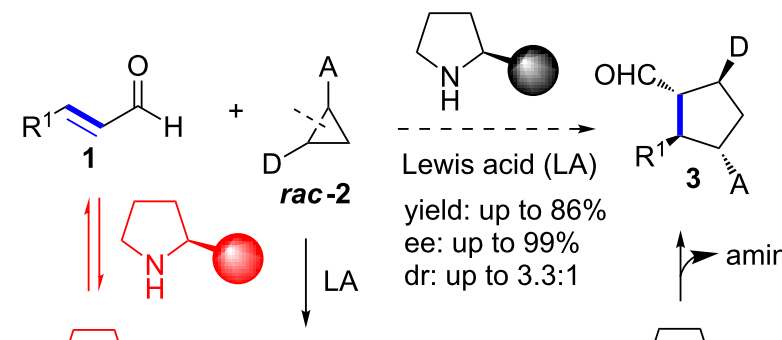

Reaction 2
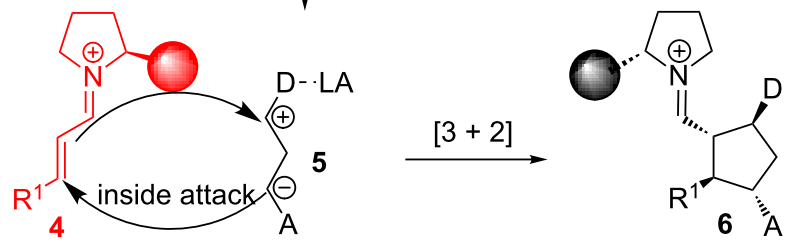


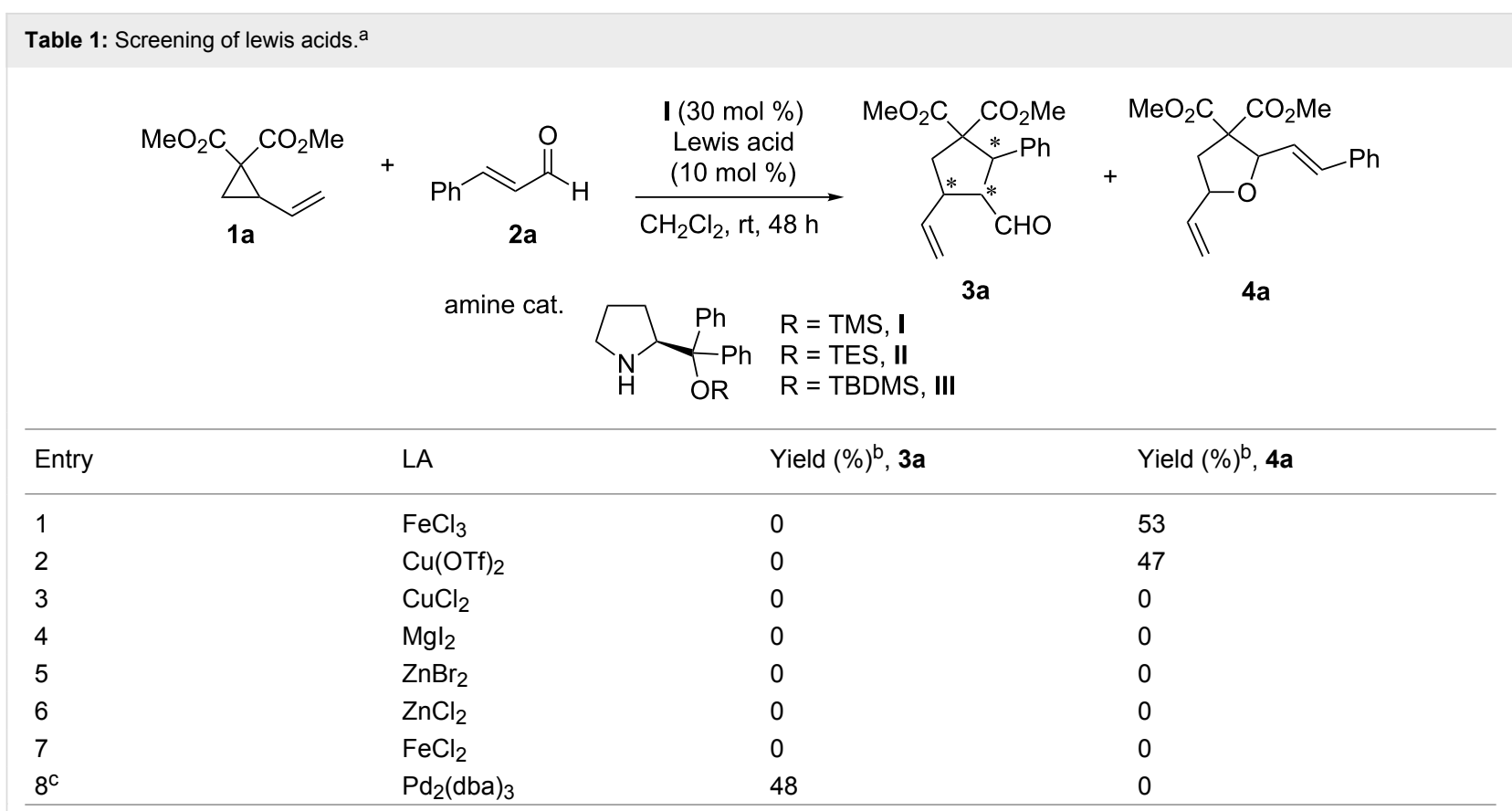

aThe reaction was carried out with $1 \mathrm{a}(36.8 \mathrm{mg}, 0.2 \mathrm{mmol})$ and $2 \mathrm{a}(26.4 \mathrm{mg}, 0.2 \mathrm{mmol})$ in the presence of $10 \mathrm{~mol} \% \mathrm{LA}$ and $30 \mathrm{~mol} \%$ amine I in $0.8 \mathrm{~mL}$ of $\mathrm{CH}_{2} \mathrm{Cl}_{2}$ at rt for $48 \mathrm{~h}$. ' ${ }^{\text {Is }}$ olated yields; ${ }^{\mathrm{c}} 5 \mathrm{~mol} \% \mathrm{Pd}_{2}(\mathrm{dba})_{3}$ and $12.5 \mathrm{~mol} \%$ dppe was used.

$\mathrm{MgI}_{2}, \mathrm{ZnBr}_{2}, \mathrm{ZnCl}_{2}$ and $\mathrm{FeCl}_{2}$ failed to promote these processes (Table 1, entries 3-7). Inspired by Trost's work of $\operatorname{Pd}(0)$ catalyzed annulations of $\mathrm{D}-\mathrm{A}$ cyclopropanes with $\mathrm{C}=\mathrm{C}$ double bonds with Meldrum's acid and alkylidenes or azlactone alkylidenes [45], we probed the $\mathrm{Pd}_{2}(\mathrm{dba})_{3}$-dppe complex for the 1,4addition cycloaddition reaction (Table 1 , entry 8 ). It was found that the reaction took place to afford the desired cyclopentane 3a.

Encouraged by this result, we carried out further investigations of the co-catalysts promoted process (Table 2). First, we determined the diastereo- and enantioselectivity of the reaction. The ${ }^{1} \mathrm{H}$ NMR of the reaction crude mixture showed three diastereoisomers. The two major diastereoisomers were determined to be $(2 S, 3 S, 4 S)-\mathbf{3 a}$ ' and $(2 S, 3 S, 4 R)-\mathbf{3 a} \mathbf{a}$ ' in 2:1 ratio (Table 2, entry 1) based on single $X$-ray crystallographic analysis (see Scheme 2). Unfortunately, the third diastereoisomer 3a", was too hard to be separated to determine its stereochemistry. The enantioselectivities of two major diastereoisomers are even more encouraging ( 80 and $76 \%$ ee). Further investigations of solvents revealed the medium-dependent effect (Table 2, entries $1-8$ ). No reaction happened in toluene (Table 2, entry 2). Disappointing outcomes were also received in DCE, ether, $\mathrm{CH}_{3} \mathrm{CN}$ and EtOAc (Table 2, entries 3-6). Gratifyingly, in $\mathrm{CHCl}_{3}$ this reaction proceeded smoothly to furnish the desired cyclopentanes in $63 \%$ yield with $99 \%$ ee for major 3a' and $83 \%$ ee for minor 3a" with a dr ratio of 1.7:1 (Table 2, entry 7). The reaction performed in THF was interesting: No reaction occurred at rt (Table 2, entry 8 ), but at $50{ }^{\circ} \mathrm{C}, 54 \%$ yield with high enantioselectivity for both isomers while $\mathbf{3 a}$ "' as the major product (dr: 3a':3a' $=5: 1$, Table 2, entry 9) was obtained. We decided to further optimize the reaction in $\mathrm{CHCl}_{3}$ accordingly (Table 2, entries 10-13). A longer reaction time helped to increase the reaction yield ( $60 \mathrm{~h}, 76 \%$ yield entry 10$)$. More steric hindered amine catalysts with bigger TES and TBDMS groups, II and III, were then probed and gave rise to the slight drop of enantioseletivity (Table 2, entries 11 and 12). A further optimization of reaction conditions found that the addition of additional 0.5 equiv $1 \mathrm{a}$ into the reaction mixture in 4 portions significantly improved the reaction yield ( $83 \%$, Table 2 , entry 13$)$. In order to improve the diastereoselectivity of this reaction, other cyclopentanes used in Trost's system were also tested in this reaction [45]. Unfortunately, the reactions proceeded slowly to afford the cycloaddition products in less than $10 \%$ yield.

We then selected the use of co-catalysts of $\mathrm{Pd}_{2}(\mathrm{dba})_{3}$ and organocatalyst $\mathbf{I}$ in $\mathrm{CHCl}_{3}$ at room temperature to evaluate the generality of this $[3+2]$ annulation process by the variation of vinylcyclopropanes and enals (Table 3 ). The results exhibit that the synergistic catalyzed enantioselective $[3+2]$ annulation process serves as a general approach to structurally chiral cyclopentanes bearing 3-consecutive stereogenic centers with high regio- and enantioselectivities. It was found that a wide range of aromatic $\alpha, \beta$-unsaturated aldehydes can effectively participate in the process (Table 3, entries 1-12). The aromatic $\alpha, \beta$-unsaturated aldehydes tethering electron-neutral, -with- 
Table 2: The optimization of reaction conditions. ${ }^{a}$<smiles>C=CC1CC1(C(C)=O)C(C)=O</smiles>

1a<smiles>O=C/C=C/c1ccccc1</smiles>

2a amine cat.

(30 $\mathrm{mol} \%$ ) $5 \mathrm{~mol} \% \mathrm{Pd}_{2}(\mathrm{dba})_{3}$ $12.5 \mathrm{~mol} \%$ dppe solvent, rt, $8 \mathrm{~h}$<smiles>C=CC1CC(C(=O)OC)(C(OC)OC)C(P([18F])[18F])[C@H]1C=O</smiles>

3a' 3a"

\begin{tabular}{|c|c|c|c|c|c|}
\hline Entry & Amine cat. & Solvent & Yield (\%) $)^{b}$ & ee $\left(3 a ', 3 a{ }^{\prime \prime}\right)^{c}$ & $d r\left(3 a^{\prime}: 3 a^{\prime \prime}\right)^{d}$ \\
\hline 1 & I & $\mathrm{CH}_{2} \mathrm{Cl}_{2}$ & 48 & 80,76 & $2: 1$ \\
\hline 2 & I & toluene & - & - & - \\
\hline 3 & I & DCE & $<20$ & - & - \\
\hline 4 & 1 & ether & $<20$ & - & - \\
\hline 5 & I & $\mathrm{CH}_{3} \mathrm{CN}$ & $<20$ & - & - \\
\hline 6 & I & EtOAc & $<20$ & - & - \\
\hline 7 & I & $\mathrm{CHCl}_{3}$ & 63 & 99,83 & $1.7: 1$ \\
\hline 8 & I & THF & - & - & - \\
\hline $9^{e}$ & I & THF & 54 & 90,90 & $1: 5$ \\
\hline $10^{f}$ & I & $\mathrm{CHCl}_{3}$ & 76 & 99,83 & $1.7: 1$ \\
\hline $11^{f}$ & II & $\mathrm{CHCl}_{3}$ & 76 & 96,80 & $1.7: 1$ \\
\hline $12^{f}$ & III & $\mathrm{CHCl}_{3}$ & 61 & 97,82 & $1.7: 1$ \\
\hline $13^{f, g}$ & 1 & $\mathrm{CHCl}_{3}$ & 83 & 99,83 & $1.7: 1$ \\
\hline
\end{tabular}

aThe reaction was carried out with $1 \mathrm{a}(36.8 \mathrm{mg}, 0.2 \mathrm{mmol})$ and $2 \mathrm{a}(26.4 \mathrm{mg}, 0.2 \mathrm{mmol})$ in the presence of $5 \mathrm{~mol} \% \mathrm{Pd}_{2}\left(\mathrm{dba}_{3}, 12.5 \mathrm{~mol} \% \mathrm{dppe}\right.$ and $30 \mathrm{~mol} \%$ organic catalyst in $0.8 \mathrm{~mL}$ of solvent at rt for $48 \mathrm{~h}$. ${ }^{\mathrm{b}}$ Isolated yields. ${ }^{\mathrm{C}}$ Determined by HPLC analysis. ${ }^{\mathrm{d}}$ Determined by ${ }^{1} \mathrm{H}$ NMR spectroscopy of the crude mixture. ${ }^{\mathrm{e}}$ The reaction was run at $50{ }^{\circ} \mathrm{C}$. ${ }^{\mathrm{T}}$ The reaction was stirred for $60 \mathrm{~h}$. 9Additional 0.5 equiv $1 \mathrm{a}$ in $0.4 \mathrm{~mL}$ of $\mathrm{CHCl} 3 \mathrm{was}$ added into the reaction mixture in 4 portions every $12 \mathrm{~h}$.<smiles>C=C[C@H]1CC(C(C)=O)(C(C)=O)[C@H](c2ccccc2Cl)[C@H]1C(=O)NCc1ccc(Br)cc1</smiles>

$7 h^{\prime}$

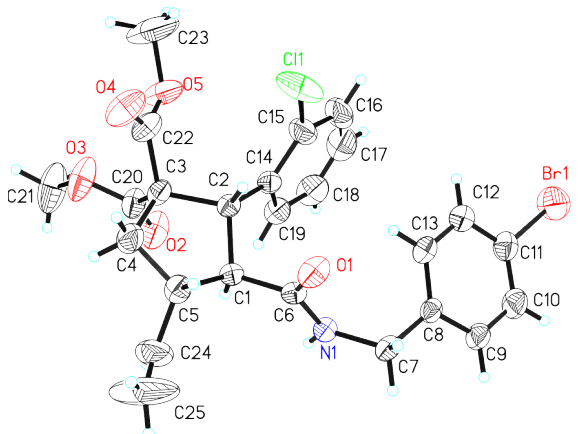<smiles></smiles>

$7 \mathrm{~h} "$

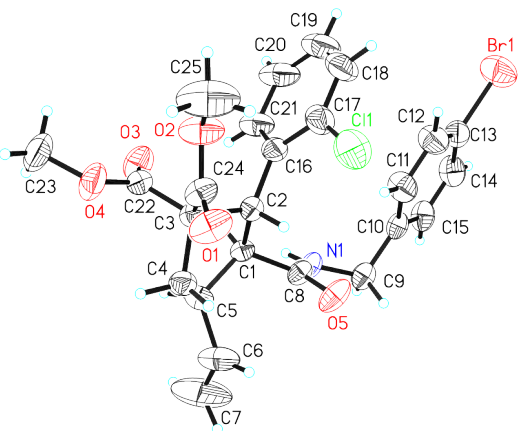

Scheme 2: Single X-ray crystal structures of $7 h^{\prime}$ and $7 h^{\prime \prime}$.

drawing, and -donating substituents at the para-position of the phenyl ring gave good to high yields and excellent enantioselectivities for major isomer 3' and minor 3"' products, while the electronic effect on enantioselectivity is more pronounced for minor 3" (Table 3, entries 1-5). A similar trend is observed with the aromatic $\alpha, \beta$-unsaturated aldehydes with electron-withdrawing at meta-position (Table 3, entries 6 and 7). Those with electron-withdrawing, and -donating groups at ortho-position 
Table 3: Scope of the $[3+2]$ annulation reaction of D-A cyclopropanes with enals. ${ }^{a}$

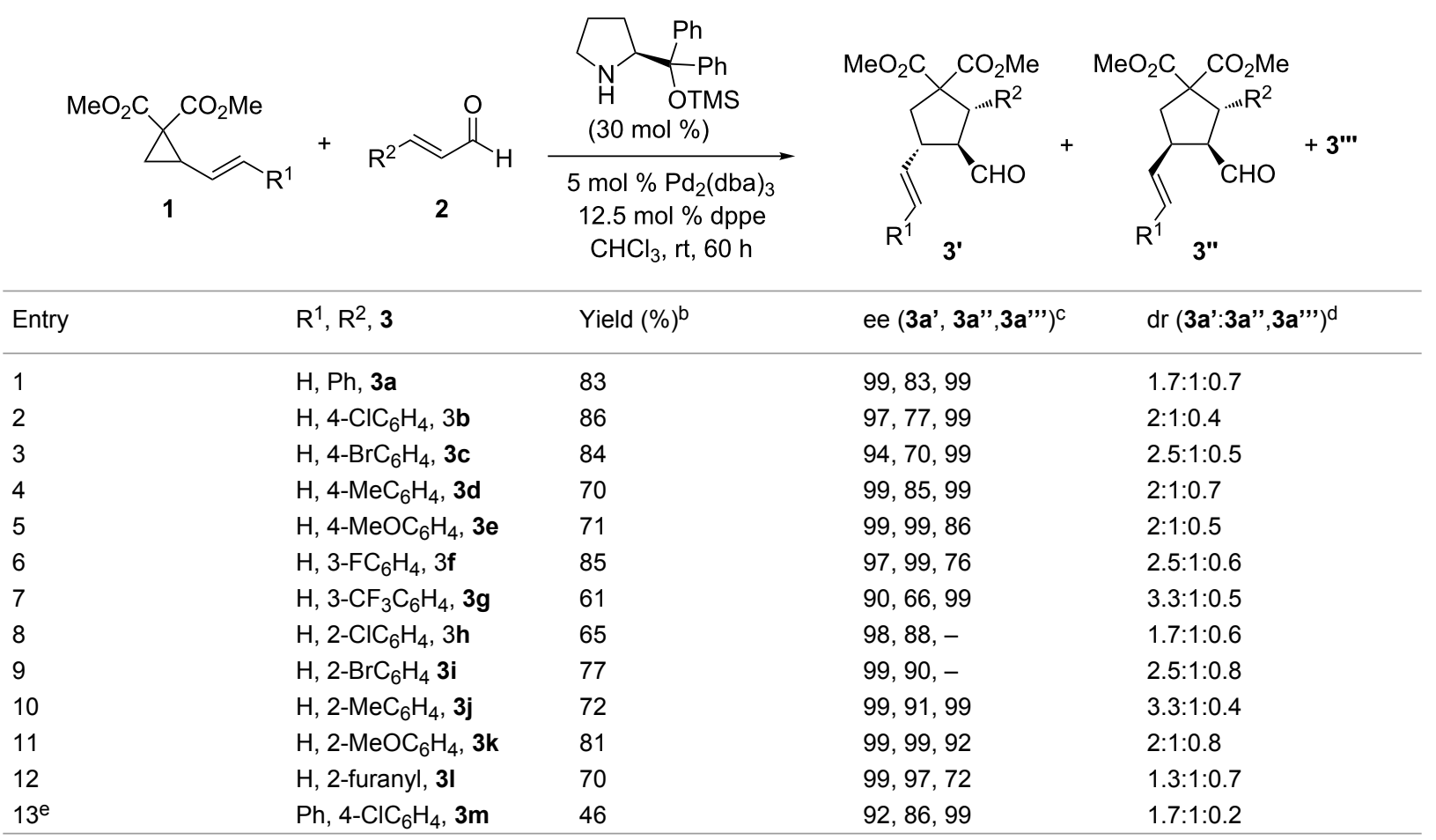

aUnless specified, see experimental section for details. ${ }^{b}$ Isolated yields. ${ }^{c}$ Determined by HPLC analysis. ${ }^{\mathrm{d}}$ Determined by ${ }^{1} \mathrm{H}$ NMR spectroscopy of crude product. ${ }^{\mathrm{e}}$ The reaction was run at $50^{\circ} \mathrm{C}$ for $120 \mathrm{~h}$.

furnished excellent enantioselectivities for both 3' and 3'' products in cases studied (Table 3, entries 8-11). Moreover, the heteroaromatic furanyl $\alpha, \beta$-unsaturated aldehyde $\mathbf{2 l}$ can also be tolerated with good yield and $97 \%$ ee for the major product (Table 3, entry 12). More significantly, the more steric demanding D-A cyclopropane bearing a phenyl ring instead of $\mathrm{H}$ can effectively participate in the process to deliver the desired product with achieving an excellent level of enantioselectivity albeit a relatively low yield (Table $3,46 \%$, entry 13 ). It is noteworthy that although aliphatic enals also can engage in this $[3+2]$ annulation reaction. Unfortunately, we could not separate them on chiral HPLC column for the determination of the enantioselectivity by all means we have attempted (data not shown).

The absolute configuration of cyclopentanes 3' and 3', were determined based on the derivatives $7 \mathbf{h}^{\prime}$, and $\mathbf{7 h}$ ', of $\mathbf{3 h}$ (Scheme 2) [95].

We proposed two possible transition states (TS) 8a' and $\mathbf{8 a}$ " to rationalize the observed configurations (Scheme 3). The trans$\mathrm{C}=\mathrm{C}$ double bond in iminium ion $\mathbf{4}$ dictates the $\mathrm{R}$ group at pseudo axial position in the cyclic 5-membered ring TS 8a' and 8a". This orientation avoids the $\mathrm{A}[1,3]$ strain induced by the catalyst-derived enamine. The $\mathrm{Pd}(\mathrm{II})-\pi 3$ complex moiety at

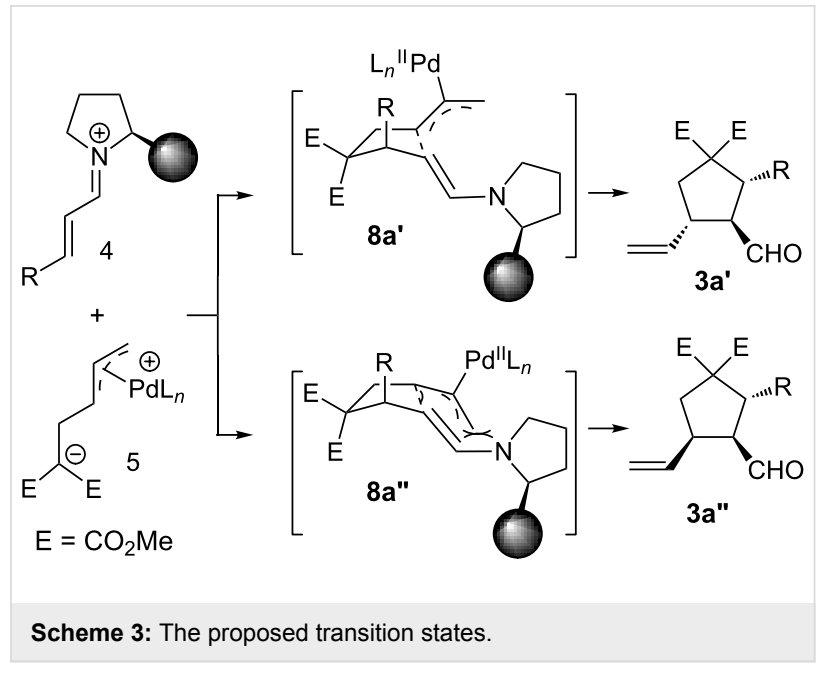

pseudo axial and equatorial positions leads to respective TS 8a' and $\mathbf{8 a}$ ", while $\mathbf{8} \mathbf{a}^{\prime}$ is more stable due to the minimization of the $\mathrm{A}[1,3]$ interaction. Therefore, it is observed 3a' produced from corresponding 8a' as the major diastereomer whereas 3a" as minor one.

\section{Conclusion}

We have developed a cooperative catalytic strategy for highly regio- and enantioselective $[3+2]$ cycloaddition reactions of 
vinylcyclopropanes with $\alpha, \beta$-unsaturated aldehydes for the first time. The combination of a chiral iminium catalyst, which activates the $\mathrm{C}=\mathrm{C}$ bond and blocks the $\mathrm{C}=\mathrm{O}$ bond in enals, and a Lewis acid promoting to open the vinylcyclopropanes enables the annulation process to proceed with the challenging $\mathrm{C}=\mathrm{C}$ bond. A high level of enantioselectivity could be achieved here. This previously unattainable $[3+2]$ annulation transformation serves as a general approach to the preparation of new densely functionalized chiral cyclopentanes. This synergistic catalysis strategy holds great potentials for further exploration of new cycloaddition reactions involving enals and other D-A systems. The endeavor is being pursued in our laboratories.

\section{Experimental}

\section{General procedure for the $[3+2]$ annulation}

A mixture of 1a $(0.2 \mathrm{mmol}, 36.8 \mathrm{mg}), \mathbf{2 a}(0.2 \mathrm{mmol}, 26.4 \mathrm{mg})$, $\mathrm{Pd}_{2}(\mathrm{dba})_{3}(0.01 \mathrm{mmol}, 9.2 \mathrm{mg})$, dppe $(0.025 \mathrm{mmol}, 10 \mathrm{mg})$ and I $(0.06 \mathrm{mmol}, 18.5 \mathrm{mg})$ in $0.8 \mathrm{~mL} \mathrm{CHCl}_{3}$ was stirred for $60 \mathrm{~h}$ at rt. During this period, $1 \mathrm{a}(0.1 \mathrm{mmol}, 18.4 \mathrm{mg})$ in $0.4 \mathrm{~mL} \mathrm{CHCl}_{3}$ was added into the solution for total 4 times every $12 \mathrm{~h}$, the mixture was purified by column chromatography on silica gel, eluted by petroleum ether/EtOAc $=20: 1$ to $10: 1$ to give the desired product $\mathbf{3 a}$ in $83 \%$ yield as a colorless oil.

\section{Supporting Information}

\section{Supporting Information File 1}

Experimental and analytical data.

[http://www.beilstein-journals.org/bjoc/content/ supplementary/1860-5397-12-127-S1.pdf]

\section{Acknowledgements}

Financial support of this research from the program for Professor of Special Appointment (Eastern Scholar) at Shanghai Institutions of Higher Learning (No. 201226, H. L.), the National Science Foundation of China (No. 21372073, W. W.), the Fundamental Research Funds for the Central Universities and East China University of Science and Technology (start-up funds, H. L. and W. W.), and the China 111 Project (Grant B07023, H. L. and W.W.) is gratefully acknowledged.

\section{References}

1. Danishefsky, S. Acc. Chem. Res. 1979, 12, 66-72. doi:10.1021/ar50134a004

2. Verhé, R.; de Kimpe, N. Synthesis and Reactivity of Electrophilic Cyclopropanes. In The Carbonyl Group; Rappoport, Z., Ed.; PATAI'S Chemistry of Functional Groups, Vol. 1 and 2; John Wiley \& Sons: Chichester, United Kingdom, 1987; pp 445-564. doi:10.1002/0470023449.ch9
3. Reissig, H.-U. Organic Synthesis via Cyclopropanes: Principles and Applications. In Cyclopropyl Group; Rappoport, Z., Ed.; PATAI'S Chemistry of Functional Groups, Vol. 1 and 2; John Wiley \& Sons: Chichester, United Kingdom, 1987; pp 375-443. doi:10.1002/0470023449.ch8

4. Salaün, J. Cyclopropane Derivatives and their Diverse Biological Activities. In Small Ring Compounds in Organic Synthesis VI; de Meijere, A., Ed.; Topics in Current Chemistry, Vol. 207; Springer: Berlin, Germany, 2000; pp 1-67. doi:10.1007/3-540-48255-5_1

5. Reissig, H.-U.; Zimmer, R. Chem. Rev. 2003, 103, 1151-1196. doi:10.1021/cr010016n

6. Yu, M.; Pagenkopf, B. L. Tetrahedron 2005, 61, 321-347. doi:10.1016/j.tet.2004.10.077

7. Carson, C. A.; Kerr, M. A. Chem. Soc. Rev. 2009, 38, 3051-3060. doi:10.1039/b901245c

8. Lebold, T. P.; Kerr, M. A. Pure Appl. Chem. 2010, 82, 1797-1812. doi:10.1351/PAC-CON-09-09-28

9. Mel'nikov, M. Ya.; Budynina, E. M.; Ivanova, O. A.; Trushkov, I. V. Mendeleev Commun. 2011, 21, 293-301. doi:10.1016/j.mencom.2011.11.001

10. Wang, Z. Synlett 2012, 23, 2311-2327. doi:10.1055/s-0032-1317082

11. Tang, P.; Qin, Y. Synthesis 2012, 44, 2969-2984. doi:10.1055/s-0032-1317011

12. Cavitt, M. A.; Phun, L. H.; France, S. Chem. Soc. Rev. 2014, 43, 804-818. doi:10.1039/C3CS60238A

13. Schneider, T. F.; Kaschel, J.; Werz, D. B. Angew. Chem., Int. Ed. 2014, 53, 5504-5523. doi:10.1002/anie.201309886

14. Stork, G.; Gregson, M. J. Am. Chem. Soc. 1969, 91, 2373-2374. doi:10.1021/ja01037a032

15. Stork, G.; Grieco, P. A. J. Am. Chem. Soc. 1969, 91, 2407-2408. doi:10.1021/ja01037a059

16. Stork, G.; Marx, M. J. Am. Chem. Soc. 1969, 91, 2371-2373. doi:10.1021/ja01037a031

17. Stork, G.; Grieco, P. A. Tetrahedron Lett. 1971, 1807-1810. doi:10.1016/S0040-4039(01)87467-0

18. Corey, E. J.; Balanson, R. D. Tetrahedron Lett. 1973, 14, 3153-3156. doi:10.1016/S0040-4039(00)79797-8

19. Danishefsky, S.; Dynak, J.; Hatch, E.; Yamamoto, M. J. Am. Chem. Soc. 1974, 96, 1256-1259. doi:10.1021/ja00811a068

20. Danishefsky, S.; Tsai, M. Y.; Dynak, J. J. Chem. Soc., Chem. Commun. 1975, 7-8. doi:10.1039/c39750000007

21. Danishefsky, S.; McKee, R.; Singh, R. K. J. Am. Chem. Soc. 1977, 99 , 7711-7713. doi:10.1021/ja00465a054

22. de Meijere, A. Angew. Chem., Int. Ed. Engl. 1979, 18, 809-826. doi:10.1002/anie.197908093

23. Wenkert, E.; Alonso, M. E.; Buckwalter, B. L.; Chou, K. J. J. Am. Chem. Soc. 1977, 99, 4778-4782. doi:10.1021/ja00456a040

24. Piers, E.; Reissig, H.-U. Angew. Chem., Int. Ed. Engl. 1979, 18, 791-792. doi:10.1002/anie.197907911

25. Wenkert, E. Acc. Chem. Res. 1980, 13, 27-31. doi:10.1021/ar50145a005

26. Reissig, H.-U.; Hirsch, E. Angew. Chem., Int. Ed. Engl. 1980, 19, 813-814. doi:10.1002/anie.198008131

27. Reissig, H.-U. Tetrahedron Lett. 1981, 22, 2981-2984. doi:10.1016/S0040-4039(01)81805-0

28. Brückner, C.; Reissig, H.-U. J. Chem. Soc., Chem. Commun. 1985, 1512-1513. doi:10.1039/C39850001512

29. Brückner, C.; Reissig, H.-U. Angew. Chem., Int. Ed. Engl. 1985, 24 , 588-589. doi:10.1002/anie.198505881 
30. Grimm, E. L.; Zschiesche, R.; Reissig, H. U. J. Org. Chem. 1985, 50, 5543-5545. doi:10.1021/jo00350a022

31. Reißig, H.-U.; Reichelt, I.; Lorey, H. Liebigs Ann. Chem. 1986, 1986, 1924-1939. doi:10.1002/jlac.198619861113

32. Brueckner, C.; Reissig, H. U. J. Org. Chem. 1988, 53, 2440-2450. doi:10.1021/jo00246a010

33. Reissig, H.-U.; Holzinger, H.; Glomsda, G. Tetrahedron 1989, 45 , 3139-3150. doi:10.1016/S0040-4020(01)80140-X

34. Reissig, H.-U. Donor-acceptor-substituted cyclopropanes: Versatile building blocks in organic synthesis. Small ring compounds in organic synthesis III; Top. Curr. Chem., Vol. 144; Springer: Berlin, Germany, 1988; pp 73-135. doi:10.1007/BFb0111229

35. Campbell, M. J.; Johnson, J. S.; Parsons, A. T.; Pohlhaus, P. D.; Sanders, S. D. J. Org. Chem. 2010, 75, 6317-6325. doi:10.1021/j01010735

36. Parsons, A. T.; Johnson, J. S. J. Am. Chem. Soc. 2009, 131, 3122-3123. doi:10.1021/ja809873u

37. Benfatti, F.; de Nanteuil, F.; Waser, J. Org. Lett. 2012, 14, 386-389. doi:10.1021/ol203144v

38. de Nanteuil, F.; Serrano, E.; Perrotta, D.; Waser, J. J. Am. Chem. Soc. 2014, 136, 6239-6242. doi:10.1021/ja5024578

39. Benfatti, F.; de Nanteuil, F.; Waser, J. Chem. - Eur. J. 2012, 18, 4844-4849. doi:10.1002/chem.201103971

40. Parsons, A. T.; Smith, A. G.; Neel, A. N.; Johnson, J. S. J. Am. Chem. Soc. 2010, 132, 9688-9692. doi:10.1021/ja1032277

41. Xu, H.; Qu, J.-P.; Liao, S.; Xiong, H.; Tang, Y. Angew. Chem., Int. Ed. 2013, 52, 4004-4007. doi:10.1002/anie.201300032

42. de Nanteuil, F.; Waser, J. Angew. Chem., Int. Ed. 2011, 50, 12075-12079. doi:10.1002/anie.201106255

43. Xiong, H.; Xu, H.; Liao, S.; Xie, Z.; Tang, Y. J. Am. Chem. Soc. 2013, 135, 7851-7854. doi:10.1021/ja4042127

44. Shimizu, I.; Ohashi, Y.; Tsuji, J. Tetrahedron Lett. 1985, 23 , 3825-3828. doi:10.1016/S0040-4039(00)89261-8

45. Trost, B. M.; Morris, P. J.; Sprague, S. J. J. Am. Chem. Soc. 2012, 134, 17823-17831. doi:10.1021/ja309003x

46. Sträter, N.; Lipscomb, W. N.; Klabunde, T.; Krebs, B. Angew. Chem., Int. Ed. Engl. 1996, 35, 2024-2055. doi:10.1002/anie.199620241

47. Sawamura, M.; Sudoh, M.; Ito, Y. J. Am. Chem. Soc. 1996, 118, 3309-3310. doi:10.1021/ja954223e

48. Xu, H.; Zuend, S. J.; Woll, M. G.; Tao, Y.; Jacobsen, E. N. Science 2010, 327, 986-990. doi:10.1126/science.1182826

49. Krautwald, S.; Sarlah, D.; Schafroth, M. A.; Carreira, E. M. Science 2013, 340, 1065-1068. doi:10.1126/science.1237068

50. Allen, A. E.; MacMillan, D. W. C. Chem. Sci. 2012, 3, 633-658. doi:10.1039/c2sc00907b

51. Ahire, M. M.; Mhaske, S. B. Angew. Chem., Int. Ed. 2014, 53, 7038-7042. doi:10.1002/anie.201400623

52. Meazza, M.; Ceban, V.; Pitak, M. B.; Coles, S. J.; Rios, R. Chem. - Eur. J. 2014, 20, 16853-16857. doi:10.1002/chem.201404565

53. Logan, K. M.; Smith, K. B.; Brown, M. K. Angew. Chem., Int. Ed. 2015, 54, 5228-5231. doi:10.1002/anie.201500396

54. Zhu, S.; Zhang, J.; Chen, K.; Jiang, H. Angew. Chem., Int. Ed. 2015, 54, 9414-9418. doi:10.1002/anie.201504964

55. Peng, H.; Akhmedov, N. G.; Liang, Y.-F.; Jiao, N.; Shi, X. J. Am. Chem. Soc. 2015, 137, 8912-8915. doi:10.1021/jacs.5b05415

56. Wang, S.; Li, X.; Liu, H.; Xu, L.; Zhang, J.; Li, J.; Li, H.; Wang, W. J. Am. Chem. Soc. 2015, 137, 2303-2310. doi:10.1021/ja511143b

57. Shao, Z.; Zhang, H. Chem. Soc. Rev. 2009, 38, 2745-2755. doi:10.1039/b901258n
58. de Armas, P.; Tejedor, D.; García-Tellado, F. Angew. Chem., Int. Ed. 2010, 49, 1013-1016. doi:10.1002/anie.200906018

59. Zhong, C.; Shi, X. Eur. J. Org. Chem. 2010, 2999-3025. doi:10.1002/ejoc.201000004

60. Rueping, M.; Koenigs, R. M.; Atodiresei, I. Chem. - Eur. J. 2010, 16, 9350-9365. doi:10.1002/chem.201001140

61. Zhou, J. Chem. - Asian J. 2010, 5, 422-434. doi:10.1002/asia.200900458

62. Loh, C. C. J.; Enders, D. Chem. - Eur. J. 2012, 18, 10212-10225. doi:10.1002/chem.201200287

63. Patil, N. T.; Shinde, V. S.; Gajula, B. Org. Biomol. Chem. 2012, 10, 211-224. doi:10.1039/C1OB06432K

64. Pellissier, H. Tetrahedron 2013, 69, 7171-7210. doi:10.1016/j.tet.2013.06.020

65. Du, Z.; Shao, Z. Chem. Soc. Rev. 2013, 42, 1337-1378. doi:10.1039/C2CS35258C

66. Ibrahem, I.; Córdova, A. Angew. Chem., Int. Ed. 2006, 45, 1952-1956. doi:10.1002/anie.200504021

67. Bihelovic, F.; Matovic, R.; Vulovic, B.; Saicic, R. N. Org. Lett. 2007, 9 , 5063-5066. doi:10.1021/ol7023554

68. Usui, I.; Schmidt, S.; Breit, B. Org. Lett. 2009, 11, 1453-1456. doi:10.1021/ol9001812

69. Capdevila, M. G.; Benfatti, F.; Zoli, L.; Stenta, M.; Cozzi, P. G. Chem. - Eur. J. 2010, 16, 11237-11241. doi:10.1002/chem.201001693

70. Ikeda, M.; Miyake, Y.; Nishibayashi, Y. Angew. Chem., Int. Ed. 2010, 49, 7289-7293. doi:10.1002/anie.201002591

71. Yoshida, A.; Ikeda, M.; Hattori, G.; Miyake, Y.; Nishibayashi, Y. Org. Lett. 2011, 13, 592-595. doi:10.1021/ol1027865

72. Motoyama, K.; Ikeda, M.; Miyake, Y.; Nishibayashi, Y. Eur. J. Org. Chem. 2011, 2239-2246. doi:10.1002/ejoc.201100044

73. Sinisi, R.; Vita, M. V.; Gualandi, A.; Emer, E.; Cozzi, P. G. Chem. - Eur. J. 2011, 17, 7404-7408. doi:10.1002/chem.201100729

74. Afewerki, S.; Ibrahem, I.; Rydfjord, J.; Breistein, P.; Córdova, A. Chem. - Eur. J. 2012, 18, 2972-2977. doi:10.1002/chem.201103366

75. Ma, G.; Afewerki, S.; Deiana, L.; Palo-Nieto, C.; Liu, L.; Sun, J.; Ibrahem, I.; Córdova, A. Angew. Chem., Int. Ed. 2013, 52, 6050-6054. doi:10.1002/anie.201300559

76. Krautwald, S.; Schafroth, M. A.; Sarlah, D.; Carreira, E. M. J. Am. Chem. Soc. 2014, 136, 3020-3023. doi:10.1021/ja5003247

77. Wang, H.; Yang, W.; Liu, H.; Wang, W.; Li, H. Org. Biomol. Chem. 2012, 10, 5032-5035. doi:10.1039/c2ob25682g

78. Sathishkannan, G.; Srinivasan, K. Org. Lett. 2011, 13, 6002-6005. doi:10.1021/ol2024423

79. Laugeois, M.; Ponra, S.; Ratovelomanana-Vidal, V.; Michelet, V.; Vitale, M. R. Chem. Commun. 2016, 52, 5332-5335. doi:10.1039/C6CC01775D

80. Goldberg, A. F. G.; O’Connor, N. R.; Craig, R. A.; Stoltz, B. M. Org. Lett. 2012, 14, 5314-5317. doi:10.1021/ol302494n

81. Zu, L.; Li, H.; Xie, H.; Wang, J.; Jiang, W.; Tang, T.; Wang, W. Angew. Chem., Int. Ed. 2007, 46, 3732-3734. doi:10.1002/anie.200700485

82. Wang, J.; Li, H.; Xie, H.; Zu, L.; Shen, X.; Wang, W. Angew. Chem., Int. Ed. 2007, 46, 9050-9053. doi:10.1002/anie.200703163

83. Vignola, N.; List, B. J. Am. Chem. Soc. 2004, 126, 450-451. doi:10.1021/ja0392566

84. Enders, D.; Wang, C.; Bats, J. W. Angew. Chem., Int. Ed. 2008, 47, 7539-7542. doi:10.1002/anie.200802532

85. Tan, B.; Shi, Z.; Chua, P. J.; Zhong, G. Org. Lett. 2008, 10 , 3425-3428. doi:10.1021/ol801246m 
86. Tan, B.; Chua, P. J.; Zeng, X.; Lu, M.; Zhong, G. Org. Lett. 2008, 10, 3489-3492. doi:10.1021/ol801273x

87. Hong, B.-C.; Nimje, R. Y.; Lin, C.-W.; Liao, J.-H. Org. Lett. 2011, 13, 1278-1281. doi:10.1021/ol1030487

88. Hong, B.-C.; Dange, N. S.; Hsu, C.-S.; Liao, J.-H.; Lee, G.-H. Org. Lett. 2011, 13, 1338-1341. doi:10.1021/ol200006e

89. Tan, B.; Candeias, N. R.; Barbas, C. F., III. Nat. Chem. 2011, 3, 473-477. doi:10.1038/nchem.1039

90. Albertshofer, K.; Tan, B.; Barbas, C. F., III. Org. Lett. 2012, 14, 1834-1837. doi:10.1021/ol300441z

91. Zhao, G.-L.; Ibrahem, I.; Dziedzic, P.; Sun, J.; Bonneau, C.; Córdova, A. Chem. - Eur. J. 2008, 14, 10007-10011. doi:10.1002/chem.200801082

92. Sun, W.; Zhu, G.; Wu, C.; Hong, L.; Wang, R. Chem. - Eur. J. 2012, 18, 6737-6741. doi:10.1002/chem.201200478

93. Remeš, M.; Veselý, J. Eur. J. Org. Chem. 2012, 3747-3752. doi:10.1002/ejoc.201200334

94. Liu, G.; Shirley, M. E.; Van, K. N.; McFarlin, R. L.; Romo, D. Nat. Chem. 2013, 5, 1049-1057. doi:10.1038/nchem.1788

95. CCDC-1032267 and -1032268 for compounds $7 h^{\prime}$ and $\mathbf{7 h " ,}$ respectively contain the supplementary crystallographic data for this paper. These data can be obtained free of charge via http://www.ccdc.cam.ac.uk.

\section{License and Terms}

This is an Open Access article under the terms of the Creative Commons Attribution License (http://creativecommons.org/licenses/by/2.0), which permits unrestricted use, distribution, and reproduction in any medium, provided the original work is properly cited.

The license is subject to the Beilstein Journal of Organic Chemistry terms and conditions:

(http://www.beilstein-journals.org/bjoc)

The definitive version of this article is the electronic one which can be found at:

$\underline{\text { doi:10.3762/bjoc. } 12.127}$ 